\title{
Isolation of Pellicular Cobalamin-binding Proteins of the Cobalamin Uptake System of Euglena gracilis
}

\author{
By FUMIO WATANABE, TOSHIAKI ITO, $†$ TOSHIKO TABUCHI, \\ YOSHIHISA NAKANO* AND SHOZABURO KITAOKA \\ Department of Agricultural Chemistry, University of Osaka Prefecture, Sakai, Osaka 591, Japan
}

(Received 3 February 1987; revised 6 July 1987)

Euglena gracilis pellicle, separated by sucrose density gradient centrifugation, had a high cobalamin $(\mathrm{Cbl})$ binding activity. Of the $\mathrm{Cbl}$ binding protein $65 \%$ was solubilized from $E$. gracilis pellicle by using $0 \cdot 1 \% \mathrm{SDS} / 2 \mathrm{M}$-urea and the residual $35 \%$ by using $1 \%(\mathrm{w} / \mathrm{v}) \mathrm{SDS}$. Both of the $\mathrm{Cbl}$ binding protein fractions showed a broad $\mathrm{pH}$ dependence for the binding of $\mathrm{Cbl}$. No evidence for the involvement of SH-groups or metal ions in $\mathrm{Cbl}$ binding was obtained. The $K_{\mathrm{s}}$ values for cyanocobalamin of the proteins solubilized with $0.1 \%$ SDS $/ 2$ M-urea and with $1 \%$ SDS were 0.22 and $0.19 \mathrm{nM}$, respectively. The $M_{\mathrm{r}}$ of a $\mathrm{Cbl}$ binding polypeptide of each protein was estimated to be 38000 by SDS-PAGE. The Cbl binding protein solubilized with $0 \cdot 1 \% \mathrm{SDS} / 2 \mathrm{M}$ urea was purified to homogeneity. Inhibition experiments on $\mathrm{Cbl}$ uptake in $E$. gracilis cells, using an antibody against the $\mathrm{Cbl}$ binding protein solubilized with $0.1 \% \mathrm{SDS} / 2 \mathrm{M}$-urea, showed that the $\mathrm{Cbl}$ binding proteins solubilized with $0.1 \% \mathrm{SDS} / 2 \mathrm{M}$-urea and $1 \% \mathrm{SDS}$ take part in the slower secondary phase and in the initial rapid phase of $\mathrm{Cbl}$ uptake in E. gracilis, respectively.

\section{INTRODUCTION}

The mechanism of cobalamin $(\mathrm{Cbl})$ uptake has been studied extensively in mammalian and bacterial cells. In mammals, especially humans, several studies suggest that $\mathrm{Cbl}$ bound to transcobalamin-II (TC-II), one of the plasma carrier proteins, is bound to the cell surface receptor and internalized by pinocytosis (Seligman \& Allen 1978; Youngdahl-Turner et al., 1979). In Escherichia coli Cbl uptake has been reported to be a biphasic process, consisting of Cbl binding to a cell surface receptor, which is a rapid initial phase, (Digirolamo \& Bradbeer, 1971) and active transport coupled to metabolic energy, which is a slower secondary phase (Bradbeer \& Woodrow, 1976). Some Cbl binding proteins have been purified from the cell envelope and from the periplasmic space of $E$. coli and have been well characterized (Kadner, 1978; Taylor $e t$ al., 1972).

The kinetics of $\mathrm{Cbl}$ uptake in the protozoa Euglena gracilis Z (Sarhan et al., 1980) and Ochromonas malhamensis (Bradbeer, 1971) are biphasic, as in E. coli. There is no other detailed information available on $\mathrm{Cbl}$ uptake in these organisms. E. gracilis $\mathrm{Z}$, which requires $\mathrm{Cbl}$ for growth, is suitable for the preparation of Cbl-limited cells (Ross, 1952) and is thus useful for the elucidation of the $\mathrm{Cbl}$ membrane transport mechanism. In the present work we separated two $\mathrm{Cbl}$ binding proteins from the $E$. gracilis pellicle, purified one of them and studied some properties of the proteins. We also investigated their physiological roles in the Cbl system using an immunological approach.

\footnotetext{
† Present address: Ohtuka Pharmaceutical Co., Ltd, Genetic Toxicology Research Laboratories, Tokushima, Japan.

‡ Present address: Japan Bio-Rad Laboratories, Osaka Office, Osaka, Japan.

Abbreviations: Cbl, cobalamin; TC-II, transcobalamin-II; CN-Cbl, cyanocobalamin; Ado-Cbl, 5'deoxyadenosylcobalamin; Me-Cbl, methylcobalamin; OH-Cbl, hydroxocobalamin; 2-AMP-Cbl, 2-amino-2methylpropanolylcobalamin; IF, intrinsic factor.
} 


\section{METHODS}

Organism and growth. E. gracilis SM-ZK, a streptomycin-bleached mutant of E. gracilis Z, was cultured for $5 \mathrm{~d}$ at $27^{\circ} \mathrm{C}$ at $2000 \mathrm{~lx}$ in a Cbl-limited $\left(0.05 \mu \mathrm{g} \mathrm{Cbl}^{-1}\right)$ Koren-Hutner medium (Koren \& Hutner, 1967).

Preparation of pellicle. Pellicle was prepared by the modified method of Hofman \& Bouck (1976). All procedures were done at $2-4{ }^{\circ} \mathrm{C}$. Euglena gracilis cells $(100 \mathrm{~g}$ wet wt) were suspended in $500 \mathrm{ml} 100 \mathrm{mM}$-sodium phosphate buffer, $\mathrm{pH} 7 \cdot 2$, containing $0.3 \mathrm{M}$-sucrose and disrupted by sonic oscillation. The homogenate was centrifuged at $3000 \mathrm{~g}$ for $30 \mathrm{~min}$. The precipitate, which contained the pellicle, was suspended in $50 \mathrm{ml}$ of the same buffer, and the suspension was applied to a stepwise density gradient of $1.9,1.4$ and $1.0 \mathrm{M}$-sucrose in $100 \mathrm{~mm}$-sodium

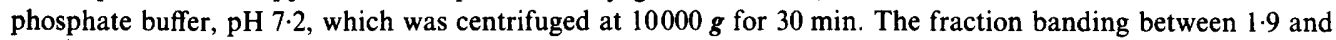
$1.4 \mathrm{M}$-sucrose, which contained most of the pellicle, was collected and diluted with $100 \mathrm{mM}$-sodium phosphate buffer, $\mathrm{pH} 7 \cdot 2$, until the sucrose concentration reached about $0.3 \mathrm{M}$. The density gradient centrifugation step was then repeated and the resulting preparation used as purified pellicle.

$\mathrm{Cbl}$ binding assay. $\mathrm{Cbl}$ binding activity was assayed by an equilibrium dialysis method. The dialysis bag containing $100 \mu \mathrm{l}$ of sample was equilibrated with $10 \mathrm{ml} 10 \mathrm{mM}$-sodium phosphate buffer, $\mathrm{pH} 7 \cdot 2$, containing $0 \cdot 5$ $\mathrm{M}, 0.0002 \% \mathrm{KCN}$ and $10 \mathrm{nM}-\left[{ }^{3} \mathrm{H}\right]$ cyanocobalamin $(\mathrm{CN}-\mathrm{Cbl})$ at $4{ }^{\circ} \mathrm{C}$ for $24 \mathrm{~h}$. After equilibrium was reached, the radioactivity of the solutions $(50 \mu \mathrm{l})$ inside and outside the bag was determined with a liquid scintillation counter (Aloka, LSC 903). The amount of Cbl bound to protein was calculated by subtracting the radioactivity in the solution outside the bag from that in the solution inside the bag. The specific activity is expressed as the amount of $\mathrm{Cbl}$ (mg protein) $)^{-1}$.

Partial purification of pellicular Cbl binding proteins. The $0 \cdot 1 \%$ SDS $/ 2$ M-urea and $1 \%$ SDS fractions, extracted from the purified pellicle, were individually applied to a column $(1.5 \times 60 \mathrm{~cm})$ of Sephadex G-25 equilibrated with

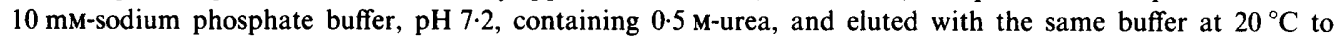
remove SDS from the proteins. Each void fraction was applied to a column $(1.5 \times 10 \mathrm{~cm})$ of DEAE-Bio-Gel A equilibrated with the same buffer. Each column was washed with $50 \mathrm{ml}$ of the buffer and eluted with $300 \mathrm{ml}$ of a linear $(0-0.4 \mathrm{M}) \mathrm{NaCl}$ gradient in the same buffer. Active fractions were pooled and concentrated using polyethylene glycol (PEG) 20000 . The concentrated solutions were applied to a column $(1.5 \times 70 \mathrm{~cm})$ of Sephacryl

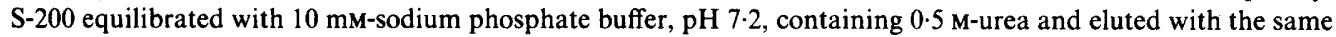
buffer. Each active fraction was combined, concentrated with PEG 20000 , and stored at $-20^{\circ} \mathrm{C}$ until use. All procedures were done at $4{ }^{\circ} \mathrm{C}$ unless otherwise specified.

Purification of the Cbl binding protein solubilized with $0 \cdot 1 \%$ SDS/2 M-urea. All purification procedures were done at $2-4{ }^{\circ} \mathrm{C}$ unless otherwise specified. The purified pellicle ( $50 \mathrm{mg}$ protein) was suspended in $1 \mathrm{ml} 100 \mathrm{~mm}$-sodium phosphate buffer, $\mathrm{pH} 7 \cdot 2$, containing $0 \cdot 1 \% \mathrm{SDS} / 2 \mathrm{M}$-urea. The suspension was incubated with stirring at $30^{\circ} \mathrm{C}$ for $1 \mathrm{~h}$ and then centrifuged at $12000 \mathrm{~g}$ for $10 \mathrm{~min}$. The precipitate was re-extracted under the same conditions and the combined supernatant fractions $(2 \mathrm{ml})$ were applied to a column $(1.5 \times 60 \mathrm{~cm})$ of Sephadex G-25 equilibrated with $10 \mathrm{~mm}$-sodium phosphate buffer, $\mathrm{pH} 7 \cdot 2$, containing $0.5 \mathrm{M}$-urea, and eluted with the same buffer at $20^{\circ} \mathrm{C}$ to remove SDS from the solubilized fraction. The void fractions were brought to $50 \%$ saturation with $\left(\mathrm{NH}_{4}\right)_{2} \mathrm{SO}_{4}$ and the precipitate was collected by centrifugation at $12000 \mathrm{~g}$ for $30 \mathrm{~min}$ and dissolved in $5 \mathrm{ml} 10 \mathrm{~mm}$-sodium

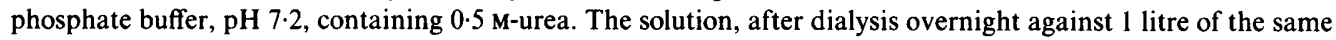
buffer, was applied to a column $(1.5 \times 25 \mathrm{~cm})$ of DEAE-Bio-Gel A equilibrated with $10 \mathrm{mM}$-sodium phosphate

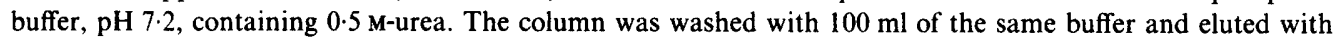
$600 \mathrm{ml}$ of a linear $(0-0.4 \mathrm{M}) \mathrm{NaCl}$ gradient in the same buffer. Active fractions, eluted at $0 \cdot 1 \mathrm{M}-\mathrm{NaCl}$, were collected and concentrated to a final volume of $2 \mathrm{ml}$ using PEG 20000 . The solution was applied to a column (1.5 $\times 70 \mathrm{~cm}$ ) of Sephacryl S-200 equilibrated with $10 \mathrm{~mm}$-sodium phosphate buffer, $\mathrm{pH} 7 \cdot 2$, containing $0.5 \mathrm{M}$-urea, and eluted with the same buffer. Active fractions were collected and applied to a column $(1.5 \times 20 \mathrm{~cm})$ of $\mathrm{CM}$ cellulose equilibrated with the same buffer. The column was washed with $100 \mathrm{ml}$ of the buffer and eluted with $600 \mathrm{ml}$ of a linear $(0-0.4 \mathrm{M}) \mathrm{NaCl}$ gradient in the same buffer. Active fractions were collected and concentrated to a final volume of $5 \mathrm{ml}$ using PEG 20000 . The concentrated solution was stored at $-20^{\circ} \mathrm{C}$ until use.

Antibody against pellicular Cbl binding protein. Purified pellicular $\mathrm{Cbl}$ binding protein $(0 \cdot 1 \mathrm{mg})$, suspended in

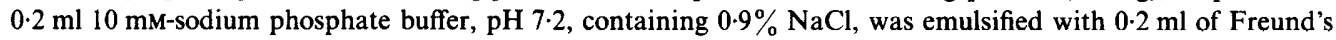
complete adjuvant. A male mouse (body weight about $50 \mathrm{~g}$ ) was injected intradermally with $0.4 \mathrm{ml}$ of the emulsion at multiple sites. A booster injection of $0.1 \mathrm{mg}$ of pellicular $\mathrm{Cbl}$ binding protein in $0.2 \mathrm{ml}$ of Freund's complete adjuvant was given 3 weeks later at the same sites. Two days after the booster injection, the mouse was bled and serum was prepared by the standard method. The IgG fraction was isolated by $\left(\mathrm{NH}_{4}\right)_{2} \mathrm{SO}_{4}$ precipitation and DEAE-cellulose ion exchange chromatography, and concentrated by $\left(\mathrm{NH}_{4}\right)_{2} \mathrm{SO}_{4}$ precipitation. The final precipitate was dissolved in $10 \mathrm{~mm}$-sodium phosphate buffer, $\mathrm{pH} 7 \cdot 2$, containing $0.9 \% \mathrm{NaCl}$ and dialysed against the same buffer.

Assay for inhibition of Cbl uptake in E. gracilis cells by the antibody against pellicular Cbl binding protein. E. gracilis cells, grown for $4 \mathrm{~d}$ in the $\mathrm{Cbl}$-limited $\left(0.05 \mu \mathrm{g} \mathrm{Cbl} 1^{-1}\right)$ medium, were washed twice with $10 \mathrm{~mm}$-sodium phosphate buffer, $\mathrm{pH} 7 \cdot 2$, containing $0.9 \%(\mathrm{w} / \mathrm{v}) \mathrm{NaCl}$ and shaken at $27{ }^{\circ} \mathrm{C}$ for $3 \mathrm{~h}$ in $50 \mathrm{ml}$ of the same buffer containing 


\section{Table 1. Solubilization of pellicular Cbl binding proteins}

Purified pellicle (11.5 mg protein) was suspended in $5 \mathrm{ml} 100 \mathrm{~mm}$-sodium phosphate buffer, $\mathrm{pH} 7 \cdot 2$, containing $0.1 \%$ SDS plus $2 \mathrm{M}$-urea and incubated at $30{ }^{\circ} \mathrm{C}$ for $1 \mathrm{~h}$ with gentle stirring. The suspension was then centrifuged at $10000 \mathrm{~g}$ for $30 \mathrm{~min}$. The supernatant was used as the $0 \cdot 1 \% \mathrm{SDS} / 2 \mathrm{M}$-urea fraction. The precipitate was resuspended in $5 \mathrm{ml}$ of the same buffer containing $1 \% \mathrm{SDS}$, incubated under the above conditions and centrifuged at $10000 \mathrm{~g}$ for $30 \mathrm{~min}$. The supernatant was used as the $1 \%$ SDS fraction.

\begin{tabular}{lcccc}
\multicolumn{1}{c}{ Fraction } & $\begin{array}{c}\text { Total protein } \\
(\mathrm{mg})\end{array}$ & $\begin{array}{c}\text { Total activity } \\
(\text { pmol Cbl bound) }\end{array}$ & $\begin{array}{c}\text { Specific activity } \\
\text { [pmol Cbl bound } \\
(\text { mg protein) })^{-1} \text { ] }\end{array}$ & $\begin{array}{c}\text { Yield } \\
(\%)\end{array}$ \\
Pellicle & $11 \cdot 5$ & $58 \cdot 0$ & $5 \cdot 0$ & 100 \\
$0.1 \%$ SDS $/ 2$ M-urea & $4 \cdot 0$ & $37 \cdot 0$ & $9 \cdot 3$ & $63 \cdot 8$ \\
$1 \%$ SDS & 6.0 & $18 \cdot 0$ & 3.0 & $31 \cdot 0$
\end{tabular}

glutamate and glucose (both $10 \mathrm{~mm})$. The antibody against pellicular $\mathrm{Cbl}$ binding protein $(0 \cdot 1 \mathrm{ml})$ was added to $0 \cdot 1 \mathrm{ml}$ of the cell suspension $\left(8.0 \times 10^{5}\right.$ cells $)$ and incubated at room temperature for $\left.2 \mathrm{~h} .{ }^{3} \mathrm{H}\right] \mathrm{CN}-\mathrm{Cbl}$ was then added to the suspension to $10^{-8} \mathrm{M}$ and the mixture was incubated at $27^{\circ} \mathrm{C}$ for $15 \mathrm{~s}$ to allow the rapid, initial phase of $\mathrm{Cbl}$ uptake and for $2 \mathrm{~min}$ to allow the initial and slower secondary phase of uptake to occur. The suspension was immediately filtered through a membrane filter (TM-2P, $24 \mathrm{~mm}$ diameter) and washed twice with the above buffer at the same temperature. The radioactivity on the membrane filter was counted using a liquid scintillation counter (Aloka, LSC 903). The Cbl uptake in the secondary phase was calculated by subtracting the radioactivity in the initial phase from that over $2 \mathrm{~min}$.

$P A G E$. Disc PAGE with $7.5 \%(\mathrm{w} / \mathrm{v})$ acrylamide at $\mathrm{pH} 9 \cdot 4$ (Davis, 1964) was done at constant current ( $2 \mathrm{~mA}$ per gel) with bromophenol blue as a migration marker. Proteins were fixed, stained with $10 \%(\mathrm{v} / \mathrm{v})$ acetic acid and $0.005 \%$ Coomassie brilliant blue R 250 in water and destained in $7 \%(\mathrm{v} / \mathrm{v})$ acetic acid in water. SDS-slab-gel electrophoresis in a linear gradient $(7.5-15 \%, \mathrm{w} / \mathrm{v})$ of polyacrylamide (Laemmli, 1970) was done at constant current $(6 \mathrm{~mA}$ per gel) with bromophenol blue as a migration marker. Proteins were fixed and stained by incubating the gels successively with: $0.005 \%$ Coomassie brilliant blue R $250,10 \%$ acetic acid and $25 \%$ (v/v) propan-2-ol in water; then with the same solution containing $10 \%$ propan-2-ol instead of $25 \%$ propan-2-ol; then with the same solution without propan-2-ol; and then destained in 7\% acetic acid in water. Rabbit muscle phosphorylase $b\left(M_{\mathrm{r}} 94000\right)$, bovine serum albumin (BSA, 67000), ovalbumin (43000), bovine erythrocyte carbonic anhydrase (30000), soybean trypsin inhibitor (20100) and bovine milk $\alpha$-lactalbumin (14400) were used as standard proteins.

For the $M_{\mathrm{r}}$ determination of partially purified $\mathrm{Cbl}$ binding proteins, the proteins obtained by DEAE-Bio-Gel A chromatography after binding $\left[{ }^{57} \mathrm{Co}\right] \mathrm{CN}-\mathrm{Cbl}$ by equilibrium dialysis and then treating with $1 \% \operatorname{SDS}$ at $30^{\circ} \mathrm{C}$ for $30 \mathrm{~min}$, were subjected to SDS-slab-gel electrophoresis. The $\mathrm{Cbl}$ binding proteins in the gel were detected by autoradiography.

Protein determinations. Protein was measured according to Bradford (1976) using BSA as standard.

Chemicals. $\left[{ }^{3} \mathrm{H}\right] \mathrm{CN}-\mathrm{Cbl}\left(5 \cdot 1 \mathrm{Ci} \mathrm{mmol}^{-1}, 188.7 \mathrm{GBq} \mathrm{mmol}^{-1}\right)$ and $\left[{ }^{57} \mathrm{Co}\right] \mathrm{CN}-\mathrm{Cbl}\left(250 \mu \mathrm{Ci} \mu \mathrm{g}^{-1}, 9 \cdot 25 \mathrm{MBq} \mu \mathrm{g}^{-1}\right)$ were obtained from New England Nuclear and Amersham, respectively. CN-Cbl, 5'-deoxyadenosylcobalamin (Ado-Cbl), methylcobalamin (Me-Cbl) and hydroxocobalamin (OH-Cbl) were obtained from Sigma. Sephacryl S-200 and the electrophoresis calibration kit were obtained from Pharmacia. Freund's complete adjuvant was obtained from Wako. DEAE-Bio-Gel A was obtained from Bio-Rad Laboratories. Membrane filters (TM-2P) were obtained from Toyo Roshi.

\section{RESULTS}

\section{Solubilization of pellicular Cbl binding proteins}

The $\mathrm{Cbl}$ binding protein was partially solubilized from $E$. gracilis pellicle using $0 \cdot 1 \%(\mathrm{w} / \mathrm{v})$ $\mathrm{SDS} / 2 \mathrm{M}$-urea. The residual $\mathrm{Cbl}$ binding protein could not be solubilized using this detergent system but could be extracted using $1 \%(\mathrm{w} / \mathrm{v})$ SDS (Table 1 ). The results suggest that several Cbl binding proteins occur in the E. gracilis pellicle. Other detergents, including Brig 35, Emulgen 910 , Lubrol PX, Triton X-100, NR 40, digitonin and deoxycholate, all at $1 \%(\mathrm{w} / \mathrm{v})$, only partially solubilized the $\mathrm{Cbl}$ binding protein (data not shown). 


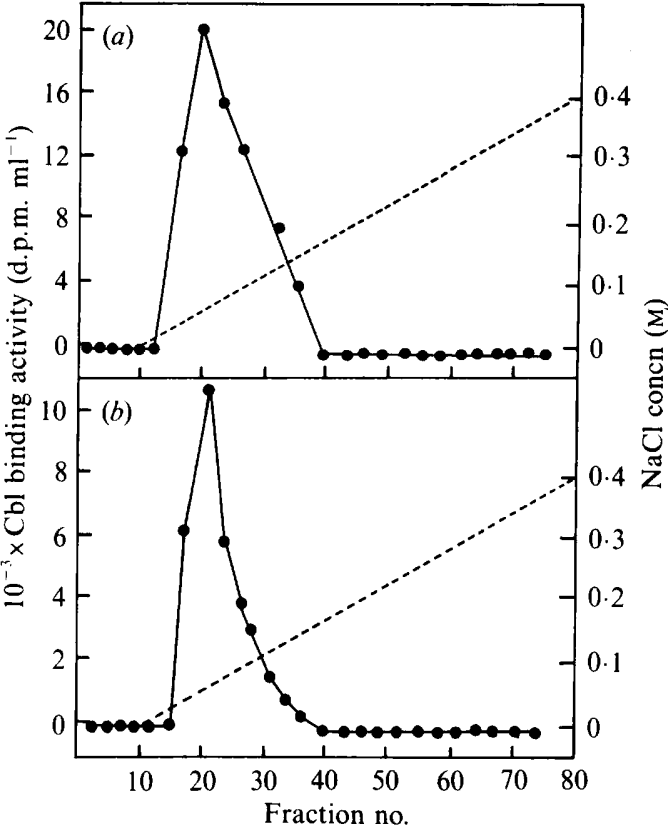

Fig. 1

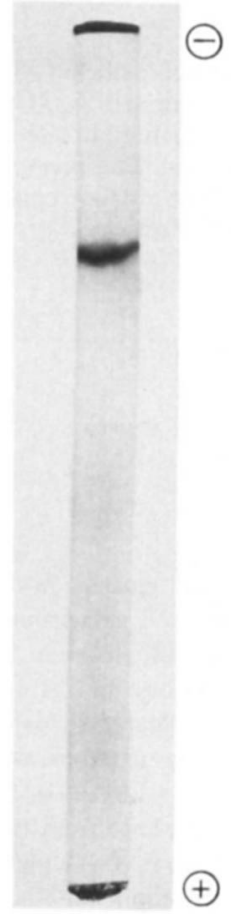

Fig. 2

Fig. 1. DEAE-Bio-Gel A column chromatography of pellicular $\mathrm{Cbl}$ binding proteins. The elution profiles of the activity in the protein solubilized with $0.1 \% \mathrm{SDS} / 2 \mathrm{M}$-urea $(a)$ and with $1 \% \mathrm{SDS}(b)$ are shown. $\mathrm{Cbl}$ binding activity; ---, $\mathrm{NaCl}$ concentration.

Fig. 2. PAGE of the purified pellicular $\mathrm{Cbl}$ binding protein $(10 \mu \mathrm{g}$ protein) solubilized with $0 \cdot 1 \%$ SDS/2 M-urea.

\section{DEAE-Bio-Gel $A$ ion exchange chromatography of pellicular Cbl binding proteins}

The elution profiles of the DEAE-Bio-Gel A column chromatography of the Cbl binding proteins solubilized by the two detergent systems are shown in Fig. $1(a, b)$. The Cbl binding activity in each of the $0.1 \% \mathrm{SDS} / 2 \mathrm{M}$-urea and $1 \% \mathrm{SDS}$ fractions was eluted as a single peak at about $0 \cdot 1 \mathrm{M}-\mathrm{NaCl}$, indicating that the two $\mathrm{Cbl}$ proteins have a similar surface potential at $\mathrm{pH} 7 \cdot 2$. Each $\mathrm{Cbl}$ binding activity was eluted as a single peak in the void volume on chromatography on Sephacryl S-200. The results suggest that each $\mathrm{Cbl}$ binding protein may be aggregated or conjugated with other proteins; however, no information on the aggregation is available.

\section{Some properties of the Cbl binding proteins}

When the $0.1 \%$ SDS $/ 2$ M-urea or $1 \%$ SDS fractions were heated at various temperatures for $10 \mathrm{~min}$ before determination of the $\mathrm{Cbl}$ binding activity, they were stable up to $40{ }^{\circ} \mathrm{C}$ and the $\mathrm{Cbl}$ binding activity was lost completely at $60^{\circ} \mathrm{C}$. Binding of $\mathrm{Cbl}$ to both pellicular binding proteins showed a broad $\mathrm{pH}$ dependence. The $0.1 \% \mathrm{SDS} / 2 \mathrm{M}$-urea and $1 \% \mathrm{SDS}$ fractions showed a maximum activity between $\mathrm{pH} 3-7$ and $\mathrm{pH} \mathrm{6-11,} \mathrm{respectively.} \mathrm{When} \mathrm{both} \mathrm{proteins} \mathrm{were}$ incubated at various $\mathrm{pH}$ values for $10 \mathrm{~min}$ at $45^{\circ} \mathrm{C}$, the $0.1 \% \mathrm{SDS} / 2 \mathrm{M}$-urea fraction was stable between $\mathrm{pH} 4$ and 8 , and at $\mathrm{pH} 10$ still showed $51 \%$ of the activity at $\mathrm{pH} 7$, while the $1 \%$ SDS fraction was stable between $\mathrm{pH} 7$ and 11 , and at $\mathrm{pH} 3$ showed $80 \%$ of the activity at $\mathrm{pH} 7$. 
Table 2. Purification of pellicular Cbl binding protein

\begin{tabular}{|c|c|c|c|c|}
\hline Step & $\begin{array}{l}\text { Total protein } \\
(\mathrm{mg})\end{array}$ & $\begin{array}{c}\text { Total activity } \\
\text { (pmol Cbl bound) }\end{array}$ & $\begin{array}{l}\text { Specific activity } \\
\text { [pmol Cbl bound } \\
(\mathrm{mg} \text { protein })^{-1} \text { ] }\end{array}$ & $\begin{array}{c}\text { Recovery } \\
(\%)\end{array}$ \\
\hline \multicolumn{5}{|l|}{ Solubilization } \\
\hline$(0 \cdot 1 \%$ SDS $/ 2$ M-urea $)$ & 151 & $475 \cdot 5$ & $3 \cdot 1$ & 100 \\
\hline$\left(\mathrm{NH}_{4}\right)_{2} \mathrm{SO}_{4}$ fractionation & $38 \cdot 0$ & $364 \cdot 7$ & $9 \cdot 6$ & $76 \cdot 7$ \\
\hline DEAE-Bio-Gel A & $23 \cdot 6$ & $342 \cdot 5$ & 14.5 & $72 \cdot 0$ \\
\hline Sephacryl S-200 & $7 \cdot 7$ & $306 \cdot 0$ & $39 \cdot 7$ & $64 \cdot 4$ \\
\hline CM-cellulose & $1 \cdot 6$ & $157 \cdot 0$ & $98 \cdot 1$ & $33 \cdot 0$ \\
\hline
\end{tabular}

Metal ions $\left(\mathrm{K}^{+}, \mathrm{Na}^{+}, \mathrm{Zn}^{2+}, \mathrm{Mn}^{2+}, \mathrm{Mg}^{2+}, \mathrm{Ca}^{2+}, \mathrm{Cu}^{2+}, \mathrm{Ni}^{2+}, \mathrm{Co}^{2+}, \mathrm{Fe}^{2+}\right.$ and $\mathrm{Fe}^{3+}$, all at $\left.1 \mathrm{mM}\right)$ had no significant effects and EDTA at $5 \mathrm{~mm}$ did not inhibit the activity, indicating that metal ions are not essential for the formation of either binding-protein-Cbl complex. Neither activity was inhibited by the $\mathrm{SH}$-inhibitors $\mathrm{N}$-ethylmaleimide, 5,5'-dithiobis(2-nitrobenzoic acid) and mersalyl (all at $1 \mathrm{~mm}$ ), suggesting that $\mathrm{SH}$-groups are not essential for $\mathrm{Cbl}$ binding activity.

Using double reciprocal plots of $\left[{ }^{3} \mathrm{H}\right] \mathrm{CN}-\mathrm{Cbl}$ concentration versus the $\mathrm{Cbl}$ binding activity of the proteins, the $K_{\mathrm{s}}$ values for $\mathrm{CN}-\mathrm{Cbl}$ of the $0.1 \% \mathrm{SDS} / 2 \mathrm{M}$-urea and $1 \% \mathrm{SDS}$ fractions were calculated to be 0.22 and $0.19 \mathrm{nM}$ respectively. CN-Cbl binding to the $0.1 \% \mathrm{SDS} / 2 \mathrm{M}$-urea fraction was inhibited $50 \%, 30 \%$ and $50 \%$ by $\mathrm{OH}-\mathrm{Cbl}, \mathrm{Me}-\mathrm{Cbl}$ and Ado-Cbl (all at $10 \mathrm{nM}$ ), respectively, while that to the $1 \%$ SDS fraction was inhibited $50 \%, 42 \%$ and $35 \%$, respectively. The results indicate that both pellicular $\mathrm{Cbl}$ binding proteins are able to bind these $\mathrm{Cbl}$ analogues as well as $\mathrm{CN}$-Cbl. However, neither $\mathrm{Cbl}$ binding activity was affected by 2-amino-2methylpropanolylcobalamin (2-AMP-Cbl), an isomer of the alkanolamine group.

The $M_{\mathrm{r}}$ values of both $\mathrm{Cbl}$ binding protein polypeptides were calculated to be 38000 by SDSslab-gel electrophoresis and autoradiography. Only a single $\mathrm{CN}-\mathrm{Cbl}$ binding polypepide was detected in each case. The purified proteins had an identical $M_{\mathrm{r}}$.

\section{Purification of the Cbl binding protein solubilized with $0 \cdot 1 \%$ SDS $2 \mathrm{M}$-urea}

This is summarized in Table 2. Disc PAGE of the Cbl binding protein after the final purification step revealed a single protein band (Fig. 2). The $\mathrm{Cbl}$ binding protein solubilized with $1 \%$ SDS was too labile to be purified to homogeneity.

\section{Effects of antibody on the purified pellicular Cbl binding protein and the purified pellicle}

When the purified pellicular $\mathrm{Cbl}$ binding protein was pretreated with antibody $(0.09 \mathrm{mg}$ protein) against the $\mathrm{Cbl}$ binding protein solubilized with $0.1 \% \mathrm{SDS} / 2 \mathrm{M}$-urea at $30^{\circ} \mathrm{C}$ for $1 \mathrm{~h}$, the $\mathrm{Cbl}$ binding activity of the protein was inhibited completely (Fig. $3 a$ ). However, the $\mathrm{Cbl}$ binding activity in the purified $E$. gracilis pellicle was inhibited only $55 \%$ by the same pretreatment with the antibody (Fig. $3 b$ ). The remaining activity in the pellicle treated with the antibody appears to be due to the presence of a $\mathrm{Cbl}$ binding protein other than the protein solubilized with $0.1 \%$ SDS/2 M-urea. This may be the protein solubilized with $1 \%$ SDS, since the antibody did not cross-react with the $1 \%$ SDS fraction.

Cbl uptake in the rapid, initial phase was inhibited about $50 \%$ by preincubation with the antibody $\left(2.0 \mathrm{mg}\right.$ protein) at $30^{\circ} \mathrm{C}$ for $1 \mathrm{~h}$, while that in the slower, secondary phase was completely inhibited by the antibody $(0.4 \mathrm{mg}$ protein) (Fig. 4). The results strongly suggest that the $\mathrm{Cbl}$ binding protein, solubilized with $0.1 \% \mathrm{SDS} / 2$ M-urea takes part in the slower secondary phase of the Cbl uptake, while the protein solubilized with $1 \%$ SDS is probably concerned with the uptake in the rapid initial phase. 


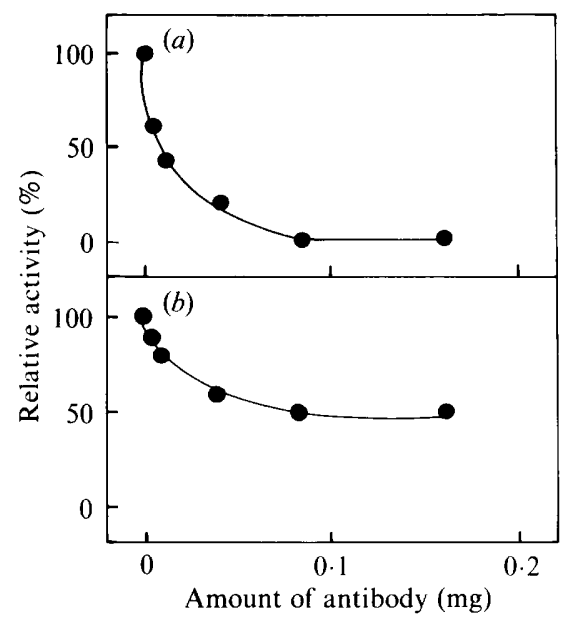

Fig. 3

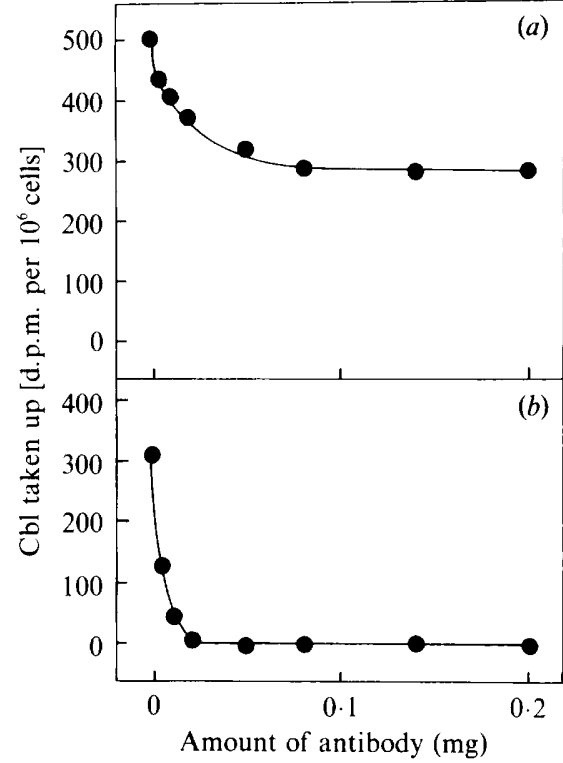

Fig. 4

Fig. 3. Effect of antibody against the protein solubilized with $0 \cdot 1 \% \mathrm{SDS} / 2 \mathrm{M}$-urea on the $\mathrm{Cb}$ binding activities of the $0.1 \% \mathrm{SDS} / 2 \mathrm{M}$-urea fraction $(a)$ and the purified pellicle $(b)$. The $\mathrm{Cbl}$ binding activity was determined after incubating the $0.1 \% \mathrm{SDS} / 2 \mathrm{M}$-urea fraction $(40 \mu \mathrm{g}$ protein) or the purified pellicle $\left(100 \mu \mathrm{g}\right.$ protein) with the indicated amounts of the antibody at $30^{\circ} \mathrm{C}$ for $1 \mathrm{~h}$. Relative activity is the activity as a percentage of that without antibody treatment.

Fig. 4. Effect of the antibody against the protein solubilized with $0 \cdot 1 \% \mathrm{SDS} / 2 \mathrm{M}$-urea on $\mathrm{Cbl}$ uptake by E. gracilis cells. $\mathrm{Cbl}$ uptake was determined $15 \mathrm{~s}$ and $2 \mathrm{~min}$ after adding to $E$. gracilis $\left(8.0 \times 10^{5}\right.$ cells $)$ which had been preincubated with the indicated amounts of antibody at room temperature for $2 \mathrm{~h}$. (a) Rapid, initial phase; $(b)$ slower, secondary phase.

\section{DISCUSSION}

Varma et al. (1961) indicated that the initial binding reaction in Cbl uptake occurred in the cell wall of $E$. gracilis Z. The data of Varma et al. (1961) and our finding that purified $E$. gracilis pellicle has a high $\mathrm{Cbl}$ binding activity (Table 1) indicate that the $\mathrm{Cbl}$ uptake system is embedded in the pellicle. Furthermore, the results of the antibody inhibition experiments indicate that both binding proteins are located in the pellicle.

Using an excellent subcellular fractionation technique, Isegawa et al. (1985) showed that Cbl taken up by $E$. gracilis $\mathrm{Z}$ is transferred to mitochondria, chloroplasts, microsomes and the cytosol within a few minutes, and that $\mathrm{Cbl}$ binding activity occurs in all organelles. Sarhan et al. (1980) suggested that the initial binding process of $\mathrm{Cbl}$ uptake occurs in the chloroplast envelope in $E$. gracilis $\mathrm{Z}$. However, since $E$. gracilis $\mathrm{Cbl}$ binding protein occurs in each organelle, the $\mathrm{Cbl}$ binding reaction in the chloroplast itself cannot be considered to take part in the Cbl uptake system.

Of the $\mathrm{Cbl}$ binding protein, $65 \%$ was solubilized from purified $E$. gracilis pellicle by $0.1 \%$ SDS $/ 2 \mathrm{M}$-urea, and the residual $35 \%$ by $1 \%$ SDS (Table 1 ). The outer membrane Cbl receptor of E. coli (White et al., 1973) and the intrinsic factor (IF)-Cbl complex receptor (Marcoulliss \& Grasbeck, 1977) have been solubilized with Triton X-100 and purified to homogeneity, but Triton X-100 did not solubilize the $E$. gracilis pellicular $\mathrm{Cbl}$ binding proteins.

$\mathrm{Ca}^{2+}$ is essential for the binding of $\mathrm{Cbl}$ to the outer membrane receptor of $E$. coli (White et al., 1973) and that of IF-Cbl complex to its receptor (Cotter et al., 1977). In our experiments, we found that $E$. gracilis pellicular $\mathrm{Cbl}$ binding proteins did not require metal ions for the formation of the protein- $\mathrm{Cbl}$ complexes and EDTA did not inhibit binding, indicating that the $\mathrm{Cbl}$ binding mechanism is different from that of the outer membrane receptor of $E$. coli. 
The $K_{\mathrm{s}}$ values of the $E$. gracilis proteins for CN-Cbl $(0.22$ and $0.19 \mathrm{nM})$, are similar to those of the outer membrane receptor and the periplasmic $\mathrm{Cbl}$ binding protein of $E$. coli $(0 \cdot 3-0 \cdot 8 \mathrm{nM})$ (Kenley et al., 1978; Bradbeer $e t$ al., 1978). The $M_{\mathrm{r}}$ of both pellicular Cbl binding proteins of $E$. gracilis was 38000 , while those of TC-II (Allen \& Majerus, 1972), IF (Allen \& Mehlman, 1973), the outer-membrane receptor (Sabet $\&$ Schnaitman, 1973) and periplasmic Cbl binding protein (Taylor et al., 1972) of E. coli are 60000,66000,60000 and 22000, respectively.

The activity of both $E$. gracilis pellicular $\mathrm{Cbl}$ binding proteins was considerably inhibited by three $\mathrm{Cbl}$ analogues, $\mathrm{OH}-\mathrm{Cbl}$, Ado-Cbl and $\mathrm{Me}-\mathrm{Cbl}$, but not by 2-AMP-Cbl, which is an isomer of the alkanolamine group of the $\mathrm{Cbl}$ molecule, indicating that the $\alpha$-coordination position of $\mathrm{Cbl}$, especially the alkanolamine moiety, is more important for the formation of the pellicular binding-protein-Cbl complexes than the $\beta$-coordination position. In IF and TC-II in mammals (Hippe et al., 1971) and the outer membrane receptor of E. coli (Kenley et al., 1978), the $\alpha$ coordination position, especially the nucleotide portion, is reported to be essential for the binding of $\mathrm{Cbl}$ to the $\mathrm{Cbl}$ binding proteins.

We thank Dr T. Kamikubo of Kobe Women's University for the gift of 2-AMP-Cbl.

\section{REFERENCES}

Allen, R. H. \& Majerus, P. W. (1972). Isolation of vitamin $B_{12}$-binding proteins using affinity chromatography III. Purification and properties of human plasma transcobalamin II. Journal of Biologial Chemistry 247, 7709-7717.

Allen, R. H. \& Mehlman, C. S. (1973). Isolation of gastric vitamin $\mathrm{B}_{12}$-binding proteins using affinity chromatography I. Purification and properties of human intrinsic factor. Journal of Biological Chemistry 248, 3660-3669.

BRADBEER, C. (1971). Transport of vitamin $B_{12}$ in Ochromonas malhamensis. Archives of Biochemistry and Biophysics 144, 184-192.

BRADBEER, C. \& WoODrow, M. L. (1976). Transport of vitamin $\mathbf{B}_{12}$ in Escherichia coli: energy dependence. Journal of Bacteriology 128, 99-104.

Bradbeer, C., Kenley, J. S., Dimasi, D. R. \& LEIGHTON, M. (1978). Transport of vitamin $B_{12}$ in Escherichia coli. Corrinoid specificities of the periplasmic $\mathbf{B}_{12}$-binding protein and of energy-dependent $B_{12}$ transport. Journal of Biological Chemistry 253, 1347-1352.

BRADFORD, M. M. (1976). A rapid and sensitive method for the quantitation of microgram quantities of protein utilizing the principle of proteindye binding. Analytical Biochemistry 72, 248254.

Cotter, R., Rothenberg, S. P. \& Weiss, J. P. (1977). Purification of the intestinal receptor for intrinsic factor by affinity chromatography. Biochimica et biophysica acta 490, 19-26.

Davis, B. D. (1964). Disc electrophoresis II. Method and application to human protein. Annals of the New York Academy of Sciences 121, 404-427.

Digirolama, P. M. \& Bradbeer, C. (1971). Transport of vitamin $\mathbf{B}_{12}$ in Escherichia coli. Journal of Bacteriology 106, 745-750.

Hippe, E., Haber, E. \& Oleson, H. (1971). Nature of vitamin $B_{12}$ binding. II. Steric orientation of vitamin $B_{12}$ on binding and number of combining sites of human intrinsic factor and the transcobalamins. Biochimica et biophysica acta 243, 75-82.

HofmanN, C. \& Bouck, S. H. (1976). Immunological and structural evidence of patterned intussusceptive surface growth in a unicellular organism. Journal of Cell Biology 69, 693-715.

Isegawa, Y., Nakano, Y. \& Kitaoka, S. (1985). Conversion and distribution of cobalamin in Euglena gracilis $\mathrm{Z}$, with special reference to its location and probable function within chloroplasts. Plant Physio$\log y$ 76, 814-818.

KADNER, R. J. (1978). Repression of synthesis of the vitamin $B_{12}$ receptor in Escherichia coli. Journal of Bacteriology 136, 1050-1057.

Kenley, J. S., Leighton, M. \& BRADbeER, C. (1978). Transport of vitamin $\mathrm{B}_{12}$ in Escherichia coli. Corrinoid specificity of the outer membrane receptor. Journal of Biological Chemistry 253, 1341-1346.

Koren, L. E. \& Hutner, S. H. (1967). High-yield media for photosynthesizing Euglena gracilis. Journal of Protozoology 14 (Supplement), 17.

LAEMMLI, U. K. (1970). Cleavage of structural proteins during the assembly of the head of bacteriophage T4. Nature, London 227, 680-685.

Marcoullis, G. \& GRASBECK, R. (1977). Solubilized intrinsic factor receptor from pig ileum and its characteristics. Biochimica et biophysica acta 496, 3651.

Ross, G. I. M. (1952). Vitamin $B_{12}$ assay in body fluids using Euglena gracilis. Journal of Clinical Pathology 5 , 250-256.

Sabet, S. T. \& Schnaitman, C. A. (1973). Purification and properties of the colicin E 3 receptor of Escherichia coli. Journal of Biological Chemistry 248, 1797-1806.

Sarhan, F., Houde, M. \& Cheneval, J. P. (1980). The role of vitamin $B_{12}$ binding in the uptake of the vitamin by Euglena gracilis. Journal of Protozoology 27, 235-238.

Seligman, P. A. \& Allen, R. H. (1978). Characterization of the receptor for transcobalamin II isolated from human placenta. Journal of Biological Chemistry 253, 1766-1772.

Taylor, R. T., Norrell, S. A. \& Hanna, M. L. (1972). Uptake of cyanocobalamin by Escherichia coli B: Some characteristics and evidence for a binding protein. Archives of Biochemistry and Biophysics 148, 366-381. 
Youngdahl-Turner, P., Mellman, I. S., Allen, R. H. \& RosenberG, L. E. (1979). Protein mediated vitamin uptake. Adsorptive endocytosis of the transcobalamin II-cobalamin complex by cultured human fibroblasts. Experimental Cell Research 118, 127-134

Varma, T. N. S., Abraham, A. \& HANSEN, I. A. (1961).
Accumulation of ${ }^{58} \mathrm{Co}$ vitamin $\mathrm{B}_{12}$ by Euglena gracilis. Journal of Protozoology 8, 212-216.

White, J. C., Digirolamo, P. M., Fu, M. L., Preston, Y. A. \& BRADBEER, C. (1973). Transport of vitamin $\mathrm{B}_{12}$ in Escherichia coli. Location and properties of the initial $B_{12}$-binding site. Journal of Biological Chemistry 248, 3978-3986. 